
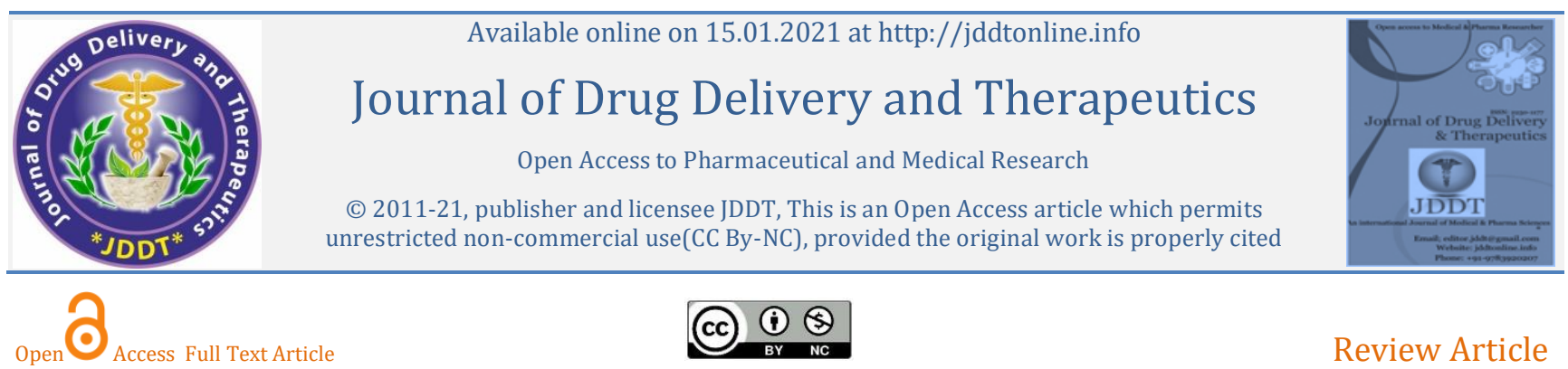

Review Article

\title{
Research Opportunities in Unani/ Greco-Arabian Medicine
}

\author{
Mohammad Hashir \\ BUMS Intern, School of Unani Medical Education and Research, Jamia Hamdard, New Delhi-110062
}

Article Info:

Article History:

Received 07 Oct 2020;

Review Completed 20 Nov 2020

Accepted 19 Dec 2020;

Available online 15 Jan 2021

*Address for Correspondence:

Mohammad Hashir. BUMS Intern, School of Unani Medical Education and Research, Jamia Hamdard, New Delhi-110062

\author{
Abstract
}

Unani medicine is a traditional system of medicine which was founded on the teachings of Hippocrates (460-377 BC). It is based on a holistic concept of health preservation, promotion and disease prevention. Mizaj (temperament), asbab-e-sitta zaruriyah (six essential factors), and tabiy'at (physis) are the basic concepts of Unani medicine which help in disease prevention as well as management. Unani medicine has a rich treasure of many effective preventive and therapeutic methods for lifestyle disorders, acute and chronic diseases, as well as psychological conditions. In this paper, we discuss the important research areas in Unani system of medicine, particularly related to present-day world.

Keywords: Unani medicine, lifestyle, chronic diseases, Mizaj

\section{Cite this article as:}

Hashir M, Research Opportunities in Unani/ Greco-Arabian Medicine, Journal of Drug Delivery and Therapeutics. 2021; 11(1):152-155 DOI: http://dx.doi.org/10.22270/jddt.v11i1.4634

\section{Introduction}

The foundation of Unani medicine was laid in ancient Greece by Buqrat, better known as Hippocrates (460-377 BC). The teachings of Hippocrates were later advanced in the medieval ages by Muslim physicians of Arabian Peninsula and neighboring countries such as Persia, Iran, Egypt, Syria etc. In later years, Indian physicians also contributed to Unani system of medicine. Hence, it is also known as GrecoArabian medicine, Persian medicine and Unani Tibb 1. Presently, India is one of the most important countries where practice of Unani medicine is concerned. It has the largest number of educational, research and health care institutions which work for the research and development of Unani medicine ${ }^{2}$. The approach of Unani medicine towards health is a holistic one. In Unani medicine, strong emphasis is placed on disease prevention and health protection through natural methods ${ }^{3}$. It offers an effective treatment for numerous respiratory, gastrointestinal, musculoskeletal, genito-urinary, cardiovascular, neurological, and lifestyle diseases 1. Al-Qanoon fil Tib of Ibn Sina (980-1035 AD), Zakhira Khwarzam Shahi of Ahmad al-Hasan Jurjani (12 ${ }^{\text {th }}$ cent. AD), Kitab al-Kulliyat of Ibn Rushd (1126-1198 AD), Kitab al-Hawi of Zakariya Razi (865-925 AD), Kamil usSana'ah of Ali Ibn Abbas Majusi (930-994 AD), Al-Tasreef of Abul Qasim Zahrawi (936-1013 AD) are some of the famous books of Unani medicine ${ }^{1,4}$. Unani medicine has rich treasure of prevention and treatment modes for various acute and chronic disorders as well as guidelines for surgical intervention 5,6 . In this paper, we hereby explore some of the important research areas in Unani medicine which can be beneficial in the present era.

\section{Basic concepts of Unani medicine}

In Unani medicine, health and disease are thought to be cause due to a derangement of mizaj (temperament) which is formed by the interaction of arkan (elements) in that organism. Hence, a particular mizaj is unique to each living being. The temperament may be damwi (hot-wet), balghami (cold-wet), safrawi (hot-dry) or saudawi (cold-dry). Mizaj depends on individual constitution, so there is no absolute normal mizaj, rather, it varies from person to person and with different ages, place of residence etc 7 . The maintenance of health depends on asbab-e-sitta zaruriya (six essential factors) which are (i) air, (ii) food and drinks, (iii) bodily movement and rest, (iv), mental movement and rest, (v) sleep and wakefulness, and (vi) excretion and retention. A balance of these factors is responsible for the maintenance of health and imbalance causes diseases ${ }^{8}$. The modes of treatment are:

a) Ilaj bit Tadbeer (Regimenal Therapy): It involves modification in asbab-e-sitta zariruya through various means such as diet modification, massage, exercise, sauna, cupping, leech therapy, venesection etc.

b) Ilaj bil dawa (Pharmacotherapy): It involves the use of various herbal, mineral and animal drugs in crude form. 
c) Ilaj bil Yad (Surgery): It is used as last resort in the treatment of tumors, chronic non-healing wounds and as a lifesaving procedure.

In addition, there is a concept of power of self-preservation or adjustment endowed by nature, called Tabiy'at (medicatrix naturae). Tabiy'at is responsible for regulating the homeostasis and also stimulating the immune response in case of disease. The health prevention and promotion methods are also aimed to focus on the strengthening of tabiy'at ${ }^{8,9}$.

\section{Unani medicine and research}

Unani system of medicine has immense opportunities of research in various fields. The research may be done to understand the basic concepts like mizaj, tabiy'at and asbab$e$-sitta zaruriya; or to scientifically approve the treatment and prevention methods like various drugs, regimental therapies and surgical procedures. Some of the areas of research interest in Unani medicine are:

1. Concept of temperament: Mizaj (temperament) is the basic concept of Unani medicine which is important for understanding all aspects of disease causation, prevention, control and treatment. Infact, ilaj bil ghiza (diet therapy) is also advised after consideration of mizaj. Hence, research may be done to understand the causation and development of temperament in detail ${ }^{10}$. A few researches done on the concept of temperament have revealed that it may be related to the blood group of a person ${ }^{11}$. A better understanding of temperament can also help in prevention of diseases ${ }^{12}$.

2. Mizaj and behavioral disorders: Behavior is directly affected by the temperament of a person, in both disease and health. Hence, in a particular disease, the temperamental changes also cause behavioral changes 13 . This changes behavior has an impact on the response to treatment. The behavioral changes caused in response to modified temperament may be studied further for clinical purposes ${ }^{14}$.

3. Ilaj bil Ghiza (Diet therapy): Unani medicine has specific diet prescription for all ailments. The diet is prescribed after considering the temperament of both the patient and the disease, in addition to age, general health, season, dwelling and many other factors. The fluid intake and types of fluids are also prescribed in detail for almost every condition. The concepts of nutrition and health maintenance are based on sound principles and clinical experience 15,16 . Hence, diet therapy is an interesting area of research in Unani system of medicine.

4. Medical and surgical emergencies: Although there is not a significant amount of literature on emergency conditions, however, some conditions like torsion of intestines, paralyticus ileus etc. have been discussed by scholars like Ibn Sina. There is important information on the functioning of intestines and how to prevent such occurrences. Medical and surgical emergency conditions can therefore be given consideration in research ${ }^{17}$.

5. Shelf-life of compound drugs: The issue of shelf-life of herbal drugs and their appropriate date of expiration has been a matter of debate for a long time ${ }^{18}$. The study of activity-based standardization of herbal drugs offers a good opportunity to determine the shelf-life of the drugs; and will also be helpful in understanding the pharmacokinetics and pharmacodynamics of these drugs 19.
6. Research on Medicinal plants: Herbal drugs used in Unani medicine contain many important medicinal compounds which help in prevention and treatment of diseases ${ }^{20}$. In Unani medicine, the drugs are mostly used in crude form 21. Scientific research on important medicinal plants will open new doors of therapy 22 .

7. Pain relief: Pain is a symptom of many acute and chronic illnesses and a cause of much agony to the patient ${ }^{23}$. Pain relief is extensively described by Ibn Sina with mild drugs to strong drugs like opium ${ }^{18}$. Analgesia can be an important area of research in Unani medicine for its wide applicability 24 .

8. Ilaj bit Tadbeer procedures: Ilaj bit Tadbeer is undoubtedly an interesting research area and most effective and valuable in the present era ${ }^{25}$. Because of its holistic nature, Ilaj bit Tadbeer is easily acceptable all over the world. Some Ilaj bit Tadbeer procedures which may be explored are:

a. Dalak (massage therapy): Due to the changing lifestyle, mental stress and chronic illnesses are on the rise 26 . Both groups of diseases require the patient to be mentally and physically relaxed before any treatment can be effective. Dalak is one such therapy which can provide both mental and physical relaxation and is also an effective therapy for pain and various other conditions 27 .

b. Taleeq (Leech therapy): Leech therapy is a popular means of treatment in Unani medicine in which living medicinal leeches are applied to the skin for sucking blood 28. It is effectively used in many disorders like arthritis 28, psoriasis, etc. In Unani medicine, leech therapy is also advised for diseases like diphtheria, tonsillitis etc., which may be explored further 29 .

c. Fasd (Venesection): Venesection involves draining out blood from specific blood vessels 30. Although venesection is mostly carried out in veins, Unani physicians have also described venesection of arteries in some diseases ${ }^{31}$. It is an effective treatment for removing plethora, congestion, and also for visceral diseases like inflammation of spleen or liver 32 .

d. Nutool (Irrigation): Also known as Shirodhara in Ayurveda 33 , Nutool involves pouring of medicated oils or decoction over body parts for a given length of time. It is a very effective therapy for relief of stress, pain and spasm. Due to its gentle and simple nature, it can be carried out with minimal medical supervision and is practically free of side effects 34 . Hence, it is a very effective and popular means of treatment and can be used in almost all age-groups. Unlike other therapies, nutool carries no adverse effects even during pregnancy and lactation 35 .

e. Kayi (Cauterization): Kayi is one of the obsolete therapies in modern day world. Presently, cauterization is used sparingly, mostly to seal bleeding points during surgery, or sometimes for removal of warts ${ }^{36}$. However, kayi in Unani medicine is described for the treatment of a wide spectrum of disorders, particularly when derangement of temperament is so much that it cannot be corrected by drugs alone 37,38 .

f. Qai (therapeutic emesis): Emesis, known as Vamana therapy in Ayurveda ${ }^{39}$, is one of the forgotten modes of treatment. However, in Unani medicine, emesis is given immense importance as a means of excreting morbid humors and restoring physiology 40. 
g. Oral diseases: Oral health and hygiene is an important part of good health ${ }^{41}$. Unani medicine has a description of various medicines which are effective in prevention of oral diseases and maintenance of healthy teeth and gums 42 .

9. Infectious diseases: Infectious diseases have caused havoc in the present century despite huge developments in antibiotics and antiseptics 43. Unani system of medicine has a description of many drugs of natural origin which have anti-bacterial, anti-viral anti-fungal effects ${ }^{44}$. Certain drugs are also described which help to clean the environment. More research on such drugs can effectively help in the control of infections 45 .

10. Chronic diseases: Unani system of medicine can be one of the best treatment options for chronic disorders because it offers a holistic approach to treatment and the constitution and temperament of the individual is taken into account ${ }^{46}$. Diseases like diabetes ${ }^{47}$, hypertension, neurological disorders, and even some types of cancers 48 can be effectively managed with Unani medicine.

\section{Conclusion}

It is evident from the above discussion that Unani medicine has ample opportunities for research and development in various areas of healthcare. With targeted researches, Unani system of medicine has the scope to challenge most of the health problems of present era.

\section{Acknowledgements}

None

\section{Conflicts of interest}

None

\section{References}

1. Islam A. Origin and development of unani medicine: An analytical study. Intellect Discourse. 2018; 26(1):23-49.

2. National Health Portal. Origin and Development of Unani Medicine in India. Centre for Health Informatics. 2015.

3. Fulder S. Remembering the holistic view. J Altern Complement Med [Internet]. 2005 Oct 1; 11(5):775-6. Available from: https://doi.org/10.1089/acm.2005.11.775

4. Nimrouzi M, Zare M. Principles of Nutrition in Islamic and Traditional Persian Medicine. J Evidence-Based Complement Altern Med. 2014 Jul; 19(4):267-70.

5. Fazil M, Nikhat S. Topical medicines for wound healing: A systematic review of Unani literature with recent advances. J Ethnopharmacol [Internet]. 2020; 257:112878. Available from: http://www.sciencedirect.com/science/article/pii/S037887411 9349827

6. Poulakou-Rebelakou E, Karamanou M, George A. The impact of ancient Greek medicine in India: the birth of Unani medicine. Acta Med Hist Adriat [Internet]. 2015;13(2):323-8. Available from: http://www.ncbi.nlm.nih.gov/pubmed/27604201

7. Fazil M, Nikhat S, Ali I. An Insight into Unani Hypoglycemic Drugs and Their Mechanism of Action. Comb Chem High Throughput Screen. 2020 Jul;

8. Ahmad S. Unani Medicine: Introduction and Present Status in India. Internet J Altern Med. 2012; 6(1):1-4.

9. Miraj S, Kiani S. A scientific correlation between dystemprament in Unani medicine and diseases: a systematic review. Electron physician. 2016 Nov; 8(11):3240-7.

10. Fazil M, Akram M, Kapoor P. General Hypochondriasis in Diabetes Mellitus Type-II (DM-II): Implications for Clinicians. GjmedphOrg.

11. Ali S, Alam M. A scientific correlation between blood groups and temperaments in Unani medicine. Indian J Tradit Knowl. 2007; 06(2):319-23.

12. Rafiean M, Khajegir A, Kiani S. The association between dystemperament and prevention of diseases: A systematic review. J Clin Diagnostic Res. 2016/09/01. 2016 Sep; 10(9):YE01-6.

13. Fazil M, Akram M, Kapoor P. Diabetes mellitus Type-II (DM-II) and disease conviction: An exploration of the possible causes. J Adv Psychol Res [Internet]. 2013; 1(2):16-21. Available from: http://www.ssjournals.com/index.php/ijapr/article/view/1422

14. Mujeeb H. Temperament - an important principle for health preservation in Tibb an-Nabawi and Unani-Tibb. Bangladesh J Med Sci [Internet]. 2017 Aug 19; 16(4):487-95. Available from: https://www.banglajol.info/index.php/BJMS/article/view/336 00

15. Alavi S. Unani medicine in the nineteenth-century public sphere: Urdu texts and the Oudh Akhbar. Indian Econ Soc Hist Rev. 2005; 42(1):101-29.

16. Moradi H, Minaii B, Nikbakht Nasrabadi A, Siahpoosh MB. Avicenna viewpoint about health preservation through healthy nutrition principles. Iran J Public Health. 2013/02/01. 2013; 42(2):220-1.

17. Khadem E, Shirazi M, Rahimi R, Bioos S, Ghorat F. Perception of paralytic ileus on viewpoint of Avicenna. Iran J Public Health. 2017 Jan; 46(1):150-2.

18. Narayana DBA, Dobriyal RM. Shelf-life of herbal remedies: challenges and approaches. In: Evaluation of Herbal Medicinal Products [Internet]. Britain: Pulok K Mukherjee, Peter J Houghton; 2009. p. 369. Available from: https://dl.uswr.ac.ir/bitstream/Hannan/130353/1/Evaluation of Herbal Medicinal Products Mukherjee Houghton (Pharm Press 2009)BBS.pdf\# page $=386$

19. Nikhat S, Fazil M. Determination of the Shelf Life and Expiry Date of Herbal Compound Drugs: a Review. Int J Sci Res Manag. 2013;1(8):415-20.

20. Ardekani MRS, Rahimi R, Javadi B, Abdi L, Khanavi M. Relationship between temperaments of medicinal plants and their major chemical compounds. J Tradit Chinese Med [Internet]. 2011; 31(1):27-31. Available from: http://www.sciencedirect.com/science/article/pii/S025462721 $160006 \mathrm{X}$

21. Revanthy SS, Rathinamala R, Murugesan M. Authentification Methods For Drugs Used in Ayurveda, Siddha, and Unani Systems of Medicine: An Overview. Intern J Pharm Sci Res. 2012; 3(8):2352-61.

22. Fazil M, Nikhat S. Nutraceutical and Pharmacological Appraisal of Āmla (Emblica officinalis Gaertn.): A Review. European J Med Plants. 2019; 1-13.

23. Brennan F, Carr DB, Cousins M. Pain management: $A$ fundamental human right. Anesth Analg. 2007; 105(1):205-21.

24. Nikhat S, Shamsi Y, Fazil M. Overcoming Pain: An Exploration of Analgesia in Ibn Sina's Al-Qanoon Fil Tibb. J Drug Deliv Ther [Internet]. 2019 May 15; 9(3):571-4. Available from: http://jddtonline.info/index.php/jddt/article/view/2755 DOI https://doi.org/10.22270/jddt.v9i3.2755

25. Minal SP, Shailesh BP, Kailaspati PC, Umesh PJ. Complementary alternative medicinal systems: An overview. J Pharm Biosci. 2018; 6(2):13.

26. Denscombe M. Social conditions for stress: Young people's experience of doing GCSEs. Br Educ Res J. 2000; 26(3):359-74.

27. Nikhat S, Fazil M. A Review on Dalk (Massage) with Special Reference to the Prescribed Mediciations. Tradit Integr Med. 2017;2(1):39-52.

28. Haycox CL, Odland PB, Coltrera MD, Raugi GJ. Indications and complications of medicinal leech therapy. J Am Acad Dermatol. 1995; 33(6):1053-5.

29. Nikhat S, Fazil M. Hirudotherapy In The Modern World-An Updated Review. Asian J Complement Altern Med. 2014; 02(05):1-6.

30. DAVIS WD, ARROWSMITH WR. The treatment of hemochromatosis by massive venesection. Ann Intern Med. 1953; 39(4):723-34.

31. Buketan Alharbi M, Alaskar S, Alqahtani TS, Saud Bin Suwailem M, Alsaleem MB, Alanizi YN, et al. The Application of Venesection (FASD) in Medical and Surgical Practice by Ibn al-Quff in the Islamic Era (1233-1286). J Res Hist Med. 2019; 8(3):191-6.

32. Nikhat S, Fazil M. Principles and practice of faşd (venesection) in unani/greco-arabian medicine. Imam J Appl Sci. 2018;3(2):33.

33. Divya Kajaria J. An Appraisal of The Mechanism of Action of Shirodhara. Ann Ayurvedic Med. 2013; 2(3):114-7.

34. Pokharel S, Sharma A. Evaluation of Insomrid tablet and 
Shirodhara in the management of Anidra (Insomnia). AYU (An Int Q J Res Ayurveda). 2010; 31(1):40.

35. Nikhat S, Fazil M. An Analytical Review on Nutool (Irrigation) Therapy. J Drug Deliv Ther. 2015; 5(5):1-4. DOI https://doi.org/10.22270/jddt.v5i5.1127

36. Fazil M, Nikhat S. Cauterization in the Work of Ibn Al Qaf Masihi (1233-1286 Ad)-Medical Heritage of 13th Century. Tradit Integr Med [Internet]. 2019 Jun 25;4(2 SE-Review Article(s)). Available from: https://jtim.tums.ac.ir/index.php/jtim/article/view/189

37. Nikhat S, Fazil M. Kayi ( Cauterization ) : A Tribute to Unani Scholars. Med J Islam World Acad Sci. 2013; 21(2):81-8.

38. Alsanad SM, Gazzaffi IMA, Salem SO, Qureshi NA. Cautery Looked through the Prisms of Shapes, Types and Methods: A Critical Appraisal. J Complement Altern Med Res. 2018; 6(2):1-19.

39. Garg N. Evaluation of the Impact of Emesis and Emesis plus Purgation Therapy. Res J Pharmacol Pharmacodyn. 2010; 2(2):201-202-202.

40. Fazil M, Nikhat S. Qai (Emesis): From Ancient To Modern Era and Its Therapeutic Efficacy in Various Disorders. J Drug Deliv Ther. 2016; 6(4):63-8. DOI https://doi.org/10.22270/jddt.v6i4.1292

41. World Health Organisation. Oral health surveys; basic methods. World Health Organization; 1977.

42. Rai A, Fazil M, Rasheed A, Ahmad B, Parveen S, Nikhat S. Role of Unani Medicines in Oro-Dental Diseases: A Comprehensive
Review and Scientific Evidence. Fortune J Heal Sci. 2020; 01(01):30-54.

43. Fazil M, Nikhat S. Exploring new horizons in health care: A mechanistic review on the potential of Unani medicines in combating epidemics of infectious diseases. Phyther Res. 2020 Nov;

44. Kalim MD, Bhattacharyya D, Banerjee A, Chattopadhyay S. Oxidative DNA damage preventive activity and antioxidant potential of plants used in Unani system of medicine. BMC Complement Altern Med [Internet]. 2010; 10(1):77. Available from: https://doi.org/10.1186/1472-6882-10-77

45. Nikhat S, Fazil M. Overview of Covid-19; its prevention and management in the light of Unani medicine. Sci Total Environ [Internet]. 2020;728:138859. Available from: http://www.sciencedirect.com/science/article/pii/S004896972 0323767

46. Shirbeigi L, Zarei A, Naghizadeh A, Vaghasloo MA. The Concept of Temperaments in Traditional Persian Medicine. Tradit Integr Med [Internet]. 2017; 2(3):143-56. Available from: http://jtim.tums.ac.ir/index.php/itim/article/view/106

47. Fazil M, Nikhat S, Akram M. Diabetes From Ancient to Modern Era. Hamdard Med. 2012; 55(1):27-31.

48. Ali I, Suhail M, Naqshbandi MF, Fazil M, Ahmad B, Sayeed A. Role of Unani Medicines in Cancer Control and Management. Curr Drug ther. 2018; 14(2):92-113. 